\title{
PENGARUH KEPEMIMPINAN, PENGAWASAN DAN SIKAP KERJA TERHADAP KINERJA PEGAWAI DI DINAS PEMBERDAYAAN MASYARAKAT DAN DESA KABUPATEN LABUHANBATU SELATAN
}

\author{
${ }^{1}$ Nurlaili Rambe, ${ }^{2}$ Eka Rafika, ${ }^{3}$ Muhammad Rahmadani Lubis, ${ }^{4}$ Paisal Pahmi Hasibuan, ${ }^{5}$ Muhammad Amsal \\ Nasution \\ 1,2,3,4,5 Universitas Islam Sumatera Utara \\ ${ }^{1}$ nurlaili.rambe@gmail.com, ${ }^{2}$ eka.rafika@gmail.com, ${ }^{3}$ rahmadani.lbs@gmail.com, ${ }_{5}^{4}$ paisal.pahmi@gmail.com, \\ ${ }^{5}$ mhd.amsal@gmail.com
}

\begin{abstract}
The formulation of problem in this research is there is influence leadership on employees performance. There is influence controlling on employees performance. There is work attitude on employees performance. There is influence of leadership, controlling and work attitude on employees performance. The purpose of this research is for know influence and analize of leadership on employees performance. For know influence and analize controlling on employees performance. For know influence and analize work attitude on employees performance. For know influence and analize leadership, controlling and work attitude on employees performance. The sample in this research is 36 employees, with data analysis technique used is multiple linear regression analysis. The research result leadership influence positive and significant on employees performance. controlling influence positive and significant to employees performance. Work attitude influence positive and significant to employees performance. Leadership, controlling and work attitude influence positive and significant to employees performance.
\end{abstract}

Keywords : Leadership, controlling, Work attitude, Performance

\begin{abstract}
ABSTRAK : Rumusan masalah dalam penelitian ini adalah bagaimana pengaruh kepemimpinan terhadap kinerja pegawai. Bagaimana pengawasan terhadap kinerja pegawai. Bagaimana pengaruh sikap kerja terhadap kinerja pegawai. Bagaimana pengaruh kepemimpinan, pengawasan dan sikap kerja terhadap kinerja pegawai Tujuan penelitian ini adalah untuk mengetahui dan menganalisis pengaruh kepemimpinan terhadap kinerja pegawai. Untuk mengetahui dan menganalisis pengaruh pengawasan terhadap kinerja pegawai. Untuk mengetahui dan menganalisis pengaruh sikap kerja terhadap kinerja pegawai. Untuk mengetahui dan menganalisis pengaruh kepemimpinan, pengawasan dan sikap kerja terhadap kinerja pegawai Sampel dalam penelitian ini berjumlah 36 orang pegawai. Teknik analisis data dalam penelitian ini menggunakan analisis deskriptif dan analisis regresi linier berganda. Hasil penelitian ini menjelaskan bahwa kepemimpinan berpengaruh positif dan signifikan terhadap kinerja pegawai. Pengawasan berpengaruh positif dan signifikan terhadap kinerja pegawai. Sikap kerja berpengaruh positif dan signifikan terhadap kinerja pegawai. Kepemimpinan, pengawasan dan sikap kerja berpengaruh positif dan signifikan terhadap kinerja pegawai.
\end{abstract}

Kata kunci : Kepemimpinan, Pengawasan, Sikap kerja, Kinerja

\section{Pendahuluan}

Kinerja Aparatur Sipil Negara merupakan suatu masalah yang cukup menarik untuk dibahas, karena akan sangat berguna bagi penegakan hukum yang juga bermanfaat baik bagi kepentingan individu, masyarakat, Bangsa dan Negara. Pada dasarnya Aparatur Sipil Negara memiliki peran dan fungsi sebagai pelaksana peraturan undang-undang yang telah ditetapkan oleh pemerintah, menjalankan fungsi pelayanan publik, dan sebagai Pengelolaan pemerintahan. Peran dan fungsi tersebut sudah 
jelas bahwa Aparatur Sipil Negara sangatlah penting. Namun tidak semua pegawai tersebut melakukan peran dan fungsinya dengan baik. Banyak pegawai yang bekerja semaunya sendiri, tidak memperhatikan hasil dari pekerjaan mereka. Untuk menciptakan pemerintahan yang baik, professional dan berwibawa, pengaruh kinerja pegawai negeri sipil yang baik akan menciptakan suasana yang aman dan nyaman karena hukum benar-benar dijadikan panglima.

Kinerja sebagai unsur sumber daya manusia di Dinas Pemberdayaan Masyarakat Dan Desa Kabupaten Labuhanbatu Selatan, masih perlu dilakukan pembenahan dengan menganalisis berbagai faktor antara lain kepemimpinan, pengawasan dan sikap kerja yang dapat mempengaruhi, mengembangkan dan memberdayakan pegawai dalam melaksanakan tugasnya untuk peningkatan kinerja dan pencapaian hasil kerja yang memuaskan secara bersama.

Pegawai di Dinas Pemberdayaan Masyarakat Dan Desa Kabupaten Labuhanbatu Selatan merupakan salah satu sumber daya organisasi yang mempunyai nilai prakarsa dan memiliki peran penting dalam pemberdayaan sumber daya lainnya di dalam instansi. Sistem pengelolaan Sumber Daya Manusia (SDM) yang tepat merupakan kunci keberhasilan organisasi untuk mencapai tujuannya. Oleh karena itu, agar tujuan dan sasaran organisasi dapat dicapai, perlu adanya perhatian yang lebih serius dari pimpinan instansi terhadap upaya-upaya dalam meningkatkan kinerja pegawai.

Pentingnya kinerja pegawai dalam melaksanakan program kerja Dinas Pemberdayaan Masyarakat Dan Desa Kabupaten Labuhanbatu Selatan semakin dirasakan. Mangkunegara (2013:67) menyatakan kinerja adalah hasil kerja secara kualitas dan kuantitas yang dicapai oleh seorang pegawai dalam melaksanakan tugasnya sesuai dengan tanggung jawab yang diberikan kepadanya. Hasibuan (2012:77), kinerja merupakan hasil kerja yang dicapai seseorang dalam melaksanakan tugasnya atas kecakapan, usaha dan kesempatan. Kinerja juga merupakan suatu hasil yang dicapai seseorang dalam melaksanakan tugas-tugas yang didasarkan atas kecakapan, pengalaman dan kesungguhan serta waktu menurut standar dan kriteria yang telah ditetapkan. Robbins (2014:116), menyatakan kinerja mempunyai makna lebih luas, bukan hanya menyatakan sebagai hasil kerja, akan tetapi juga bagaimana proses kerja berlangsung. Berdasarkan pra riset yang peneliti lakukan di Dinas Pemberdayaan Masyarakat Dan Desa Kabupaten Labuhanbatu Selatan ada beberapa permasalahan yang dapat peneliti amati terkait dengan kinerja, seperti sistem birokrasi pelayanan administrasi yang belum optimal, hal ini ditandai dengan adanya proses surat menyurat yang agak panjang proses penyelesaiannya, masih ada pegawai yang datang terlambat dan pulang sebelum jam kantor.

Faktor yang mempengaruhi kinerja pegawai di Dinas Pemberdayaan Masyarakat Dan Desa Kabupaten Labuhanbatu Selatan adalah kepemimpinan. Pemimpin berperan penting dalam menciptakan iklim kerja yang baik, solid, dan harmonis bagi pegawai guna menumbuhkan semangat kerja sehingga dapat meningkatkan kinerja serta dapat menciptakan kuantitas dan kualitas pekerjaan sesuai dengan yang diharapkan. Samsudin (2011:156) mengemukakan bahwa pemimpin harus dapat menjalin kerja sama yang baik dengan bawahan untuk mencapai tujuan organisasi. Dengan cara seperti itu, maka pemimpin akan banyak mendapat bantuan berupa pikiran, semangat, dan tenaga dari bawahan yang akan menimbulkan semangat bersama dan rasa persatuan, sehingga akan memudahkan proses pendelegasian dan pemecahan masalah yang semuanya dilakukan untuk memajukan organisasi. Hal ini sesuai dengan pendapat Siagian (2013:124) bahwa kepemimpinan adalah kemampuan dan keterampilan seseorang yang menduduki jabatan sebagai pemimpin satuan kerja untuk mempengaruhi prilaku orang lain terutama bawahannya untuk berfikir dan untuk bertindak sedemikian rupa sehingga melalui prilaku yang positif ia memberikan sumbangsih yang nyata dalam pencapaian tujuan organisasi. Untuk mencapai tujuan bersama, pegawai perlu membina kebersamaan dengan mengikuti pengendalian dari atasannya. Dengan pengendalian tersebut, perbedaan keinginan, kehendak, kemauan, perasaan, kebutuhan dan lain-lain dipertemukan untuk digerakkan kearah yang sama. Dengan demikian berarti perbedaan individual dimanfaatkan untuk mencapai tujuan yang sama sebagai kegiatan kepemimpinan atasan di Dinas Pemberdayaan Masyarakat Dan Desa Kabupaten Labuhanbatu Selatan. 
Hasil penelitian terdahulu dari Fauzi (2013) menyatakan bahwa kepemimpinan berpengaruh positif dan signifikan terhadap kinerja. Hasil penelitian Osabiya Babatunde, Ikenga Emem (2015) menyatakan gaya kepemimpinan berpengaruh positif dan signifikan terhadap kinerja. Hasil penelitian dari Sami'an dan Estu Aprilian N.W, (2013) juga menyatakan bahwa kepemimpinan berpengaruh positif dan signifikan terhadap kinerja. Sementara hasil penelitian dari Rahayu Saputri, Nur Rahmah Andayani, (2018) menyatakan kepemimpinan berpengaruh negatif dan tidak signifikan terhadap kinerja. Dari hasil penelitian terdahulu tersebut jelas adanya research gap, sehingga menarik peneliti untuk melakukan penelitian lanjutan di Dinas Pemberdayaan Masyarakat Dan Desa Kabupaten Labuhanbatu Selatan. Hal ini didukung dengan hasil wawancara yang peneliti lakukan terhadap 10 orang pegawai Dinas Pemberdayaan Masyarakat Dan Desa Kabupaten Labuhanbatu Selatan, peneliti menemukan masih ada pegawai yang merasakan diperlakukan kurang adil di dalam pembagian pekerjaan, dan menunjukkan sikap mengkritisasi beberapa bentuk kebijakan dari atasan serta perencanaan kerja dari atasan belum sepenuhnya dapat terserap oleh bawahan.

Faktor lainnya yang mempengaruhi kinerja pegawai di Dinas Pemberdayaan Masyarakat Dan Desa Kabupaten Labuhanbatu Selatan adalah pengawasan. Rivai (2014:107) menyatakan pengawasan adalah proses pengamatan dari pada pelaksanaan seluruh kegiatan organisasi untuk menjamin agar supaya semua pekerjaan yang sedang dilaksanakan berjalan sesuai dengan rencana yang telah ditentukan sebelumnya. Oleh karena itu suatu sistem pengawasan yang efektif harus dapat segera penyimpangan-penyimpangan, sehingga berdasarkan penyimpaganpenyimpagan itu dapat diambil tindakan untuk pelaksanaan selanjutnya agar pelaksanaan keseluruhan benar-benar dapat sesuai atau mendekati apa yang direncanakan sebelumnya. Suatu sistem pengawasan adalah efektif, bilamana sistem pengawasan itu memenuhi prinsip fleksibilitas. Ini berarti bahwa sistem pengawasan itu tetap dapat dipergunakan, meskipun terjadi perubahan-peruban terhadap rencana diluar dugaan. Misalnya suatu pekerjaan direncanakan selesai dalam waktu hari, berarti bahwa ukuran yang dipergunakan disini tidaklah mengandung prinsip fleksibel. Hal inilah yang perlu mendapatkan perhatian dari pihak manajerial terutama pimpinan, agar dapat sedini mungkin mencegah dan berupaya meningkatkan kualitas pengawasan. Bagaimana mungkin bila untuk mencapai tujuan yang diharapkan oleh Dinas Pemberdayaan Masyarakat Dan Desa Kabupaten Labuhanbatu Selatan, masih ada pegawai yang kurang perduli dengan apa yang harus dikerjakan dan sudah menjadi tanggung jawab itu. Padahal pegawai itu mempunyai peran yang cukup besar dalam mengembangkan potensi yang dimilikinya menyelenggarakan dan membentuk konsep kerja yang jelas. Penelitian terdahulu dari Sami'an dan Estu Aprilian N.W, (2013); Rara Saraswati (2015), dan Elvandari, Erlina Oktafia (2015), kesemuanya menyatakan pengawasan berpengaruh positif dan signifikan terhadap kinerja. Sementara hasil penelitian dari Firda Nova Manullang (2011) menyatakan pengawasan berpengaruh positif dan tidak signifikan terhadap kinerja. Penelitian terdahulu di atas menunjukkan adanya research gap, sehingga menarik peneliti untuk melakukan penelitian lanjutan di Dinas Pemberdayaan Masyarakat Dan Desa Kabupaten Labuhanbatu Selatan.

Faktor berikutnya yang mempengaruhi kinerja pegawai di Dinas Pemberdayaan Masyarakat Dan Desa Kabupaten Labuhanbatu Selatan adalah sikap kerja. Pada dasarnya sikap kerja merupakan pikiran dan perasaan puas atau tidak puas, suka atau tidak suka terhadap pekerjaannya dengan kecenderungan respon positif atau negatif untuk memperoleh hal yang diinginkannya dalam pekerjaannya. Sikap kerja ini menunjukan respon-respon setiap orang berupa emosional terhadap pekerjaan yang sedang dikerjakan, tanggung jawab terhadap pekerjaan yang dibebankan, dan rasa percaya diri ketika bekerja. Hubungan yang searah antara sikap kerja dengan kinerja dalam penelitian ini diperkuat dengan beberapa penelitian terdahulu, diantaranya Hasil penelitian terdahulu dari Chres F.P Laoh et.al (2016), Famella et.al (2015), Fonny Corryda Rahayu (2013), dan Alias et.al (2018), kesemuanya menarik kesimpulan sikap kerja berpengaruh positif dan signifikan terhadap kinerja. Sementara hasil penelitian terdahulu dari Rd. Kresna et.al (2017), menarik kesimpulan sikap kerja berpengaruh negati dan tidak terhadap kinerja. Tidak konsistennya dari penelitian terdahulu tersebut sehingga peneliti tertarik melakukan penelitian lanjutan terhadap 
pegawai di Dinas Pemberdayaan Masyarakat Dan Desa Kabupaten Labuhanbatu Selatan.

\subsection{Rumusan Masalah}

Berdasarkan batasan masalah yang telah diidentifikasi maka peneliti merumuskan masalah yang berkaitan dengan penelitian ini adalah :

1) Apakah ada pengaruh kepemimpinan terhadap kinerja pegawai di Dinas Pemberdayaan Masyarakat Dan Desa Kabupaten Labuhanbatu Selatan.

2) Apakah ada pengaruh pengawasan terhadap kinerja pegawai di Dinas Pemberdayaan Masyarakat Dan Desa Kabupaten Labuhanbatu Selatan.

3) Apakah ada pengaruh sikap kerja terhadap kinerja pegawai di Dinas Pemberdayaan Masyarakat Dan Desa Kabupaten Labuhanbatu Selatan.

4) Apakah ada pengaruh kepemimpinan, pengawasan dan sikap kerja terhadap kinerja pegawai di Dinas Pemberdayaan Masyarakat Dan Desa Kabupaten Labuhanbatu Selatan.

\subsection{Batasan Masalah}

Berdasarkan uraian di atas, banyak faktor yang berpengaruh pada variabel kinerja pegawai di Dinas Pemberdayaan Masyarakat Dan Desa Kabupaten Labuhanbatu Selatan, sehingga dalam penelitian ini peneliti membatasi kepada variabel independen yaitu kepemimpinan, pengawasan dan sikap kerja.

\subsection{Hipotesis}

Berdasarkan pada kerangka konseptual di atas, maka hipotesis dalam penelitian ini adalah

1) Ada pengaruh kepemimpinan terhadap kinerja pegawai di Dinas Pemberdayaan Masyarakat Dan Desa Kabupaten Labuhanbatu Selatan.

2) Ada pengaruh pengawasan terhadap kinerja pegawai di Dinas Pemberdayaan Masyarakat Dan Desa Kabupaten Labuhanbatu Selatan.

3) Ada pengaruh sikap kerja terhadap kinerja pegawai di Dinas Pemberdayaan Masyarakat Dan Desa Kabupaten Labuhanbatu Selatan.
4) Ada pengaruh kepemimpinan, pengawasan dan sikap kerja terhadap kinerja pegawai di Dinas Pemberdayaan Masyarakat Dan Desa Kabupaten Labuhanbatu Selatan.

\subsection{Tujuan Penelitian}

Tujuan dari penelitian ini adalah :

1) Untuk menganalisis pengaruh kepemimpinan terhadap kinerja pegawai di Dinas Pemberdayaan Masyarakat Dan Desa Kabupaten Labuhanbatu Selatan.

2) Untuk menganalisis pengaruh pengawasan terhadap kinerja pegawai di Dinas Pemberdayaan Masyarakat Dan Desa Kabupaten Labuhanbatu Selatan.

3) Untuk menganalisis pengaruh sikap kerja terhadap kinerja pegawai di Dinas Pemberdayaan Masyarakat Dan Desa Kabupaten Labuhanbatu Selatan.

4) Untuk menganalisis pengaruh kepemimpinan, pengawasan dan sikap kerja terhadap kinerja pegawai di Dinas Pemberdayaan Masyarakat Dan Desa Kabupaten Labuhanbatu Selatan

\section{Metode Penelitian \\ 2.1. Populasi}

Menurut Sugiyono (2011: 55), populasi adalah wilayah generalisasi yang terdiri atas obyek/subjek yang mempunyai kuantitas dan karakteristik tertentu yang ditetapkan oleh peneliti untuk dipelajari dan kemudian ditarik kesimpulannya. Jadi populasi bukan hanya orang tetapi juga benda-benda alam yang lain. Populasi juga bukan sekedar jumlah yang ada pada objek/subjek yang dipelajari, tetapi meliputi seluruh karakteristik, sifat yang dimiliki objek/subjek itu. Dari pengertian tersebut, maka dapat disimpulkan bahwa populasi merupakan subjek penelitian dimana individu yang akan dikenai perilaku atau dapat dikatakan sebagai keseluruhan objek penelitian yang akan diteliti. Maka yang menjadi populasi dalam penelitian ini adalah pegawai Dinas Pemberdayaan Masyarakat Dan Desa Kabupaten Labuhanbatu Selatan yang berjumlah 36 orang.

Tabel 1. Kerangka populasi pegawai

\begin{tabular}{|c|l|c|}
\hline No & \multicolumn{1}{|c|}{ Keterangan } & Jumlah (Orang) \\
\hline 1 & Sekretariat & 6 \\
\hline 2 & $\begin{array}{l}\text { Bidang Pemberdayaan dan Partisipasi } \\
\text { Masyarakat }\end{array}$ & 8 \\
\hline 3 & Bidang Usaha Masyarakat dan & 7 \\
\hline
\end{tabular}




\begin{tabular}{|c|l|c|}
\hline No & \multicolumn{1}{|c|}{ Keterangan } & Jumlah (Orang) \\
\hline & Sumber Daya Alam & 8 \\
\hline 4 & $\begin{array}{l}\text { Bidang Pemberdayaan Teknologi } \\
\text { Tepat Guna }\end{array}$ & 7 \\
\hline 5 & Bidang Pemerintahan Desa/Kelurahan & 36 \\
\hline \multicolumn{2}{|c|}{ Jumlah } \\
\hline
\end{tabular}

\subsection{Sampel}

Menurut Arikunto (2011: 78), teknik sampling merupakan teknik pengambilan sampel, sedangkan sampel adalah sebagian dari jumlah dan karanteristik yang dimiliki oleh populasi. Dengan teknik penarikan sampel secara total sampling, maka sampel dalam penelitian ini seluruh populasi yaitu 36 orang pegawai Dinas Pemberdayaan Masyarakat Dan Desa Kabupaten Labuhanbatu Selatan.

Tabel 2. Kerangka sampel pegawai

\begin{tabular}{|c|l|c|}
\hline No & \multicolumn{1}{|c|}{ Keterangan } & Jumlah (Orang) \\
\hline 1 & Sekretariat & 6 \\
\hline 2 & $\begin{array}{l}\text { Bidang Pemberdayaan dan Partisipasi } \\
\text { Masyarakat }\end{array}$ & 8 \\
\hline 3 & $\begin{array}{l}\text { Bidang Usaha Masyarakat dan } \\
\text { Sumber Daya Alam }\end{array}$ & 7 \\
\hline 4 & $\begin{array}{l}\text { Bidang Pemberdayaan Teknologi } \\
\text { Tepat Guna }\end{array}$ & 8 \\
\hline 5 & Bidang Pemerintahan Desa/Kelurahan & 36 \\
\hline \multicolumn{2}{|c|}{ Jumlah } \\
Sumber: Dinas Pemberdayaan Masyarakat Dan Desa Kabupaten Labuhanbatu Selatan, 2021
\end{tabular}

\subsection{Uji Normalitas}

Uji normalitas adalah untuk melihat apakah nilai residual terdistribusi normal atau tidak. Model regresi yang baik adalah memiliki nilai residual yang terdistribusi normal. Jadi uji normalitas bukan dilakukan pada masingmasing variabel tetapi pada nilai residualnya. Sering terjadi kesalahan yang jamak yaitu bahwa uji normalitas dilakukan pada masingmasing variabel. Hal ini tidak dilarang tetapi model regresi memerlukan normalitas pada nilai residualnya bukan pada masing-masing variabel penelitian.

Pengujian normalitas data penelitian adalah untuk menguji apakah dalam model statistik variabel-variabel penelitian berdistribusi normal atau tidak normal. Model regresi yang tinggi adalah memiliki distribusi normal atau mendekati normal. Untuk menguji apakah distribusi data normal atau tidak, salah satunya dengan menggunakan metode gambar normal Probabilitas Plots digunakan untuk menyimpulkan apakah model analisis memenuhi asumsi normal, dengan penyebaran data di sekitar garis diagonal dan mengikuti arah garis diagonal maka data tersebut mememenuhi asumsi normal dalam model analisis, yang dapat dilihat pada gambar dibawah ini :

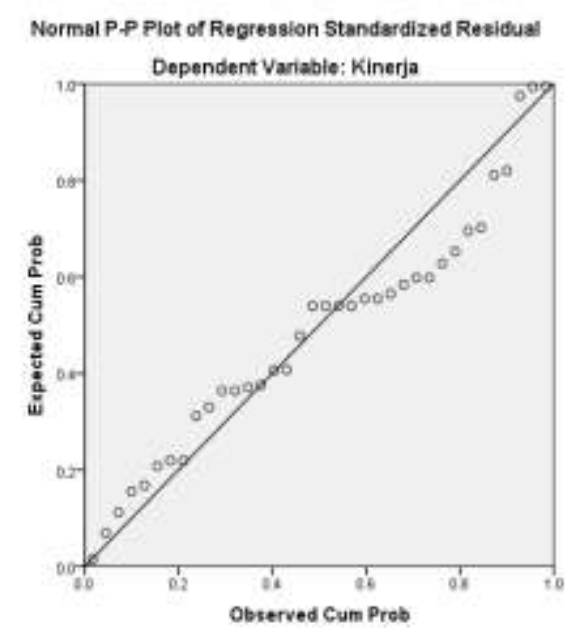

Gambar 1. Uji asumsi normalitas pengaruh kepemimpinan, pengawasan dan sikap kerja terhadap kinerja 
Tabel 3. One-Sample Kolmogorov-Smirnov Test

\begin{tabular}{|c|c|c|c|c|c|}
\hline \multirow{2}{*}{\multicolumn{2}{|c|}{$\mathrm{N}$}} & Kepemimpinan & Pengawasan & Sikap kerja & Kinerja \\
\hline & & 36 & 36 & 36 & 36 \\
\hline \multirow[b]{2}{*}{ Normal Parameters ${ }^{\mathrm{a}, \mathrm{b}}$} & Mean & 42.3889 & 40.8889 & 43.8333 & 43.0833 \\
\hline & $\begin{array}{l}\text { Std. } \\
\text { Deviation }\end{array}$ & 2.80079 & 3.69384 & 2.92282 & 3.21936 \\
\hline \multirow{3}{*}{$\begin{array}{l}\text { Most Extreme } \\
\text { Differences }\end{array}$} & Absolute & .190 & .151 & .112 & .164 \\
\hline & Positive & .190 & .151 & .112 & .164 \\
\hline & Negative & -.134 & -.077 & -.078 & -.123 \\
\hline \multirow{2}{*}{\multicolumn{2}{|c|}{$\begin{array}{l}\text { Kolmogorov-Smirnov Z } \\
\text { Asymp. Sig. (2-tailed) }\end{array}$}} & 1.140 & .904 & .670 & .985 \\
\hline & & .149 & .387 & .761 & 286 \\
\hline
\end{tabular}

Berdasarkan Tabel 3, diatas diketahui signifikansi sebesar 0.206. Nilai signifikansi ini lebih besar dari 0.05, sehingga dapat disimpulkan bahwa data yang diuji berdistribusi normal.

\subsection{Uji Asumsi Multikolinieritas}

Multikolinieritas berati adanya hubungan yang kuat diantara beberapa atau semua variabel bebas pada model regresi. Jika terdapat multikolinieritas maka koefisien regresi menjadi tidak tentu, tingkat kesalahannya menjadi sangat besar dan biasanya ditandai dengan koefisien determinasi yang sangat besar tetapi pada pengujian parsial koefisien regresi, tidak ada atau pun kalau ada sangat sedikit sekali koefisien regresi yang signifikan. Pada penelitian ini digunakan nilai Variance Inflantion Factorrs (VIF) sebagai indikator ada tidaknya multikolinearitas di antara variabel bebas.
Tabel 4. Uji asumsi multikolinieritas

\begin{tabular}{|l|c|c|}
\hline \multirow{2}{*}{ Variabel } & \multicolumn{2}{c|}{ Collinearity Statistics } \\
\cline { 2 - 3 } & Tolerance & VIF \\
\hline Kepemimpinan & 0.929 & 1.076 \\
\hline Pengawasan & 0.870 & 1.150 \\
\hline Sikap kerja & 0.911 & 1.098 \\
\hline
\end{tabular}

a Dependent Variable : Kinerja

Hasil pengolahan data, 2021

Berdasarkan nilai VIF yang diperoleh seperti terlihat pada tabel 4 diatas sebesar 1.076, 1.150, 1.098, dimana nilai VIF dari ketiga varibel bebas lebih kecil dari 10 dan dapat disimpulkan tidak terdapat multikolinieritas diantara ketiga variabel bebas dalam penelitian ini.

\subsection{Uji Asumsi Autokorelasi}

Autokorelasi sebagai suatu korelasi antara nilai variabel dengan nilai variabel yang sama pada lag satu atau lebih sebelum nya. Menurut Cornelius (2015: 212), kisaran nilai uji autokorelasi yang dilakukan dalam pengujian Durbin Watson (DW) sebagai berikut :

$1.65<\mathrm{DW}<2.35$ tidak terjadi autokorelasi 1.21. $<$ DW $<1.65$ atau $2.35<\mathrm{DW}<2.79$ tidak dapat disimpulkan.

$\mathrm{DW}<1.21$ atau $\mathrm{DW}>2.79$ terjadi autokorelasi.

Tabel 5. Autokorelasi

\begin{tabular}{|l|r|r|r|r|r|r|}
\hline \multirow{3}{*}{ Model } & \multicolumn{5}{|c|}{ Change Statistics } & \multirow{2}{*}{$\begin{array}{c}\text { Durbin- } \\
\text { Watson }\end{array}$} \\
\cline { 2 - 6 } & $\begin{array}{c}\text { R Square } \\
\text { Change }\end{array}$ & F Change & df1 & df2 & $\begin{array}{c}\text { Sig. F } \\
\text { Change }\end{array}$ & \\
\hline 1 & .535 & 12.289 & 3 & 32 & .000 & 1.914 \\
\hline
\end{tabular}

Dependent Variable: Kinerja

Hasil pengolahan data, 2021

Berdasarkan Tabel 5. di atas diperoleh nilai statistik Durbin-Watson (DW) diperoleh nilai 1.914, nilai tersebut berada pada kisaran $1.65<\mathrm{DW}<2.35$ maka dapat disimpulkan tidak terdapat autokorelasi pada model regresi. Setelah ketiga asumsi regresi diuji, selanjutnya dilakukan pengujian hipotesis.

\section{Evaluasi Data.}


Dalam evaluasi data ini peneliti akan menguji kebenaran hipotesis baik itu secara simultan atau bersama-sama, maupun secara partial atau sendiri-sendiri dan untuk memudahkan peneliti dalam pengolahan data, maka digunakan Program SPSS versi 23.00.

\subsection{Analisis Regresi Linier Berganda}

Analisis regresi linier berganda ini digunakan untuk mengestimasi pengaruh kepemimpinan, pengawasan dan sikap kerja terhadap kinerja pegawai di Dinas Pemberdayaan Masyarakat Dan Desa Kabupaten Labuhanbatu Selatan. Berdasarkan hasil pengolahan data diperoleh hasil sebagai berikut :

Tabel 5.20. Coefficients ${ }^{\mathrm{a}}$ pengaruh kepemimpinan, pengawasan dan sikap kerja terhadap kinerja

\begin{tabular}{|c|c|c|c|c|c|c|}
\hline \multirow{2}{*}{\multicolumn{2}{|c|}{ Model }} & \multicolumn{2}{|c|}{$\begin{array}{l}\text { Unstandardized } \\
\text { Coefficients }\end{array}$} & \multirow{2}{*}{$\begin{array}{c}\text { Standardized } \\
\text { Coefficients } \\
\text { Beta }\end{array}$} & \multirow{2}{*}{$\mathrm{t}$} & \multirow{2}{*}{ Sig. } \\
\hline & & B & Std. Error & & & \\
\hline 1 & (Constant) & 3.617 & 7.905 & & .458 & .650 \\
\hline & Kepemimpinan & .534 & .144 & .464 & 3.713 & .001 \\
\hline & Pengawasan & .253 & .113 & .290 & 2.243 & .032 \\
\hline & Sikap kerja & .314 & .139 & .285 & 2.257 & .031 \\
\hline
\end{tabular}

a Dependent Variable: Kinerja

Hasil pengolahan data, 2021

Berdasarkan Tabel 5.20, out put SPSS "Coefficients" diatas, persamaan regresi linier berganda adalah sebagai berikut :

$$
\begin{aligned}
& \mathrm{Y}=3.617+0.534 \mathrm{X}_{1}+0.253 \mathrm{X}_{2}+ \\
& 0.314 \mathrm{X}_{3}+\mathrm{e}
\end{aligned}
$$

Berdasarkan persamaan regresi linier berganda ini, maka dapat dijelaskan maksud dari persamaan di atas :

1) Nilai konstanta dari persamaan regresi dari penelitian ini sebesar 3.617, hal ini menyatakan bahwa nilai variabel kinerja pegawai di Dinas Pemberdayaan Masyarakat Dan Desa Kabupaten Labuhanbatu Selatan sebesar 3.617.

2) Koefisien regresi untuk variabel kepemimpinan sebesar 0.534, hal ini menjelaskan bahwa variabel kepemimpinan berpengaruh positif terhadap kinerja pegawai di Dinas Pemberdayaan Masyarakat Dan Desa Kabupaten Labuhanbatu Selatan

3) Koefisien regresi untuk variabel pengawasan sebesar 0.253, hal ini menjelaskan bahwa variabel kepemimpinan berpengaruh positif terhadap kinerja pegawai di Dinas Pemberdayaan Masyarakat Dan Desa Kabupaten Labuhanbatu Selatan

4) Koefisien regresi untuk variabel sikap kerja sebesar 0.314, hal ini menjelaskan bahwa variabel disiplin kerja berpengaruh positif terhadap kinerja pegawai di Dinas Pemberdayaan Masyarakat Dan Desa Kabupaten Labuhanbatu Selatan.

\subsection{Pengaruh Kepemimpinan Terhadap Kinerja Pegawai Di Dinas Pemberdayaan Masyarakat Dan Desa Kabupaten Labuhanbatu Selatan.}

Untuk mengetahui pengaruh kepemimpinan terhadap kinerja pegawai di Dinas Pemberdayaan Masyarakat Dan Desa Kabupaten Labuhanbatu Selatan digunakan uji$\mathrm{t}$, sedangkan untuk melihat besarnya pengaruh variabel bebas terhadap variabel terikat digunakan angka Beta atau Standardized Coefficient Beta.

\begin{tabular}{|c|c|c|c|c|c|c|}
\hline \multirow{2}{*}{\multicolumn{2}{|c|}{ Model }} & \multicolumn{2}{|c|}{$\begin{array}{l}\text { Unstandardized } \\
\text { Coefficients }\end{array}$} & \multirow{3}{*}{$\begin{array}{c}\text { Standardized } \\
\text { Coefficients } \\
\text { Beta }\end{array}$} & \multirow{2}{*}{$\mathrm{t}$} & \multirow{2}{*}{ Sig. } \\
\hline & & B & Std. Error & & & \\
\hline \multirow[t]{2}{*}{1} & (Constant) & 3.617 & 7.905 & & .458 & .650 \\
\hline & Kepemimpinan & .534 & .144 & .464 & 3.713 & .001 \\
\hline
\end{tabular}

Tabel. 6. Coeficients ${ }^{\mathrm{a}}$ pengaruh kepemimpinan terhadap kinerja

a Dependent Variable : Kinerja

Hasil pengolahan data, 2021 
Dari Tabel 6. diatas diperoleh nilai $\mathrm{t}_{\text {hitung }}$ sebesar 3.713. Penelitian ini menggunakan taraf signifikansi $(\alpha ; 0,05)$ dan Derajat Kebebasan (DK) dengan ketentuan DK $=\mathrm{n}-2$, atau $36-2$ $=34$. Dengan ketentuan tersebut, diperoleh nilai $\mathrm{t}_{\text {tabel }}$ sebesar 2.018. Dengan kriteria hipotesis sebagai berikut :

Jika $\mathrm{t}_{\text {hitung }}>\mathrm{t}_{\text {tabel }}$, maka $\mathrm{H}_{0}$ ditolak dan $\mathrm{Ha}$ diterima.

Jika $\mathrm{t}_{\text {hitung }}<\mathrm{t}_{\text {tabel }}$, maka $\mathrm{H}_{0}$ diterima dan $\mathrm{Ha}$ ditolak.

Berdasarkan hasil pengolahan data penelitian, diperoleh nilai $t_{\text {hitung }}>t_{\text {tabel }}(3.713>$ 2.018) dan nilai signifikasi $0.001<0.05$, sehingga $\mathrm{H}_{0}$ ditolak dan $\mathrm{Ha}$ diterima. Artinya variabel kepemimpinan berpengaruh positif dan signifikan terhadap kinerja pegawai di Dinas Pemberdayaan Masyarakat Dan Desa Kabupaten Labuhanbatu Selatan. Besarnya pengaruh variabel kepemimpinan terhadap kinerja pegawai di Dinas Pemberdayaan Masyarakat Dan Desa Kabupaten Labuhanbatu Selatan sebesar 0.464 atau $46.40 \%$. Hasil penelitian ini sejalan dengan hasil penelitian terdahulu dari Fauzi (2013), Osabiya Babatunde, Ikenga Emem (2015), dan Sami'an dan Estu Aprilian N.W, (2013) yang menarik kesimpulan kepemimpinan berpengaruh positif dan signifikan terhadap kinerja.

Dalam organisasi apapaun bentuknya, kepemimpinan merupakan faktor yang turut menentukan tercapainya tujuan organisasi secara lebih efektif dan efisien. Pemimpin merupakan simbol, panutan, pendorong, sekaligus sumber daya organisasi guna mencapai tujuannya. Kepemimpinan atau leadership adalah kemampuan seorang pemimpin untuk membujuk mempengaruhi serta mengarahkan orang lain yang dipimpin sehingga orang lain tersebut bekerja sebagaimana yang dikehendaki oleh pimpinan. Faktor kepemimpinan sangat memiliki peranan penting dalam suatu organisasi karena pemimpin adalah orang yang paling bertanggung jawab terhadap keberhasilan pencapaian visi dan misi dinas dan dalam pencapaian visi dan misi ini pemimpin harus bisa mengajak atau menghimbau semua bawahan atau orang yang dipimpin mengabdikan segenap kemampuan dan keahliannya untuk mencapai hasil yang diharapkan.

\subsection{Pengaruh Pengawasan Terhadap Kinerja Pegawai Di Dinas Pemberdayaan Masyarakat Dan Desa Kabupaten Labuhanbatu Selatan.}

Untuk mengetahui pengaruh pengawasan terhadap kinerja pegawai di Dinas Pemberdayaan Masyarakat Dan Desa Kabupaten Labuhanbatu Selatan digunakan uji$\mathrm{t}$, sedangkan untuk melihat besarnya pengaruh variabel bebas terhadap variabel terikat digunakan angka Beta atau Standardized Coefficient Beta.

Tabel. 7. Coeficients ${ }^{\mathrm{a}}$ pengaruh pengawasan terhadap kinerja

\begin{tabular}{|c|c|c|c|c|c|c|}
\hline \multirow{2}{*}{\multicolumn{2}{|c|}{ Model }} & \multicolumn{2}{|c|}{$\begin{array}{l}\text { Unstandardized } \\
\text { Coefficients }\end{array}$} & \multirow{3}{*}{$\begin{array}{c}\text { Standardized } \\
\text { Coefficients } \\
\text { Beta }\end{array}$} & \multirow{2}{*}{$\mathrm{t}$} & \multirow{2}{*}{ Sig. } \\
\hline & & B & Std. Error & & & \\
\hline 1 & (Constant) & 3.617 & 7.905 & & .458 & .650 \\
\hline & Pengawasan & .253 & .113 & .290 & 2.243 & .032 \\
\hline
\end{tabular}

a Dependent Variable : Kinerja

Hasil pengolahan data, 2021

Dari Tabel 7diatas diperoleh nilai $t_{\text {hitung }}$ sebesar 2.243. Penelitian ini menggunakan taraf signifikansi $(\alpha ; 0,05)$ dan Derajat Kebebasan (DK) dengan ketentuan DK $=\mathrm{n}-2$, atau $36-2$ $=34$. Dengan ketentuan tersebut, diperoleh nilai $\mathrm{t}_{\text {tabel }}$ sebesar 2.018. Dengan kriteria hipotesis sebagai berikut :

Jika $\mathrm{t}_{\text {hitung }}>\mathrm{t}_{\text {tabel }}$, maka $\mathrm{H}_{0}$ ditolak dan Ha diterima.

Jika $\mathrm{t}_{\text {hitung }}<\mathrm{t}_{\text {tabel }}$, maka $\mathrm{H}_{0}$ diterima dan $\mathrm{Ha}$ ditolak.
Berdasarkan hasil pengolahan data penelitian, diperoleh nilai $t_{\text {hitung }}>t_{\text {tabel }}(2.243>$ 2.018) dan nilai signifikasi $0.032<0.05$, sehingga $\mathrm{H}_{0}$ ditolak dan $\mathrm{Ha}$ diterima. Artinya variabel pengawasan berpengaruh positif dan signifikan terhadap kinerja pegawai di Dinas Pemberdayaan Masyarakat Dan Desa Kabupaten Labuhanbatu Selatan. Besarnya pengaruh variabel pengawasan terhadap kinerja pegawai di Dinas Pemberdayaan Masyarakat Dan Desa Kabupaten Labuhanbatu Selatan sebesar 0.290 atau 29\%. Hasil penelitian ini 
sejalan dengan hasil penelitian dari Sami'an dan Estu Aprilian N.W, (2013); Rara Saraswati (2015), dan Elvandari, Erlina Oktafia (2015), kesemuanya menyatakan pengawasan berpengaruh positif dan signifikan terhadap kinerja. Fungsi pengawasan dalam penyelenggaraan manajemen dinas (coorporation) sangat diperlukan untuk mencegah berbagai kendala pelaksanaan setiap kegiatan organisasi di lingkungan dinas. Efek yang diharapkan dari dilaksanakannya fungsi pengawasan adalah meningkatnya kinerja dinas dan prestasi kerja pegawai, dimana kinerja pegawai berkaitan dengan kemampuan masingmasing pegawai dalam melaksanakan tugastugasnya secara tepat waktu dan sesuai dengan hasil yang ditentukan. Proses mencapai kinerja yang sesuai dengan hasil yang secara standar telah ditentukan dinas melibatkan penggunaan logika untuk mencari cara-cara yang paling ekonomis untuk melaksanakan tugas kerja, peralatan dan bahan kerja, kondisi lingkungan dan ruang, serta cara-cara yang mudah dalam melaksanakan tugas kerja.

\subsection{Pengaruh Sikap Kerja Terhadap Kinerja Pegawai Di Dinas Pemberdayaan Masyarakat Dan Desa Kabupaten Labuhanbatu Selatan.}

Untuk mengetahui pengaruh sikap kerja terhadap kinerja pegawai di Dinas Pemberdayaan Masyarakat Dan Desa Kabupaten Labuhanbatu Selatan digunakan uji$\mathrm{t}$, sedangkan untuk melihat besarnya pengaruh variabel bebas terhadap variabel terikat digunakan angka Beta atau Standardized Coefficient Beta.

Tabel. 8. Coeficients ${ }^{\mathrm{a}}$ pengaruh sikap kerja terhadap kinerja

\begin{tabular}{|c|c|c|c|c|c|c|}
\hline \multirow{2}{*}{\multicolumn{2}{|c|}{ Model }} & \multicolumn{2}{|c|}{$\begin{array}{l}\text { Unstandardized } \\
\text { Coefficients }\end{array}$} & \multirow{2}{*}{$\begin{array}{c}\text { Standardized } \\
\text { Coefficients } \\
\text { Beta } \\
\end{array}$} & \multirow{2}{*}{$\mathrm{t}$} & \multirow{2}{*}{ Sig. } \\
\hline & & B & Std. Error & & & \\
\hline 1 & (Constant) & 3.617 & 7.905 & & .458 & .650 \\
\hline & Sikap kerja & .314 & .139 & .285 & 2.257 & .031 \\
\hline
\end{tabular}

Dari Tabel 8. diatas diperoleh nilai $t_{\text {hitung }}$ sebesar 2.257. Penelitian ini menggunakan taraf signifikansi $(\alpha ; 0,05)$ dan Derajat Kebebasan (DK) dengan ketentuan DK $=\mathrm{n}-2$, atau $36-2$ $=34$. Dengan ketentuan tersebut, diperoleh nilai $\mathrm{t}_{\text {tabel }}$ sebesar 2.018. Dengan kriteria hipotesis sebagai berikut :

Jika $\mathrm{t}_{\text {hitung }}>\mathrm{t}_{\text {tabel }}$, maka $\mathrm{H}_{0}$ ditolak dan $\mathrm{Ha}$ diterima.

Jika $\mathrm{t}_{\text {hitung }}<\mathrm{t}_{\text {tabel }}$, maka $\mathrm{H}_{0}$ diterima dan $\mathrm{Ha}$ ditolak.

Berdasarkan hasil pengolahan data penelitian, diperoleh nilai $t_{\text {hitung }}>t_{\text {tabel }}(2.257>$ 2.018) dan nilai signifikasi $0.031<0.05$, sehingga $\mathrm{H}_{0}$ ditolak dan $\mathrm{Ha}$ diterima. Artinya variabel sikap kerja berpengaruh positif dan signifikan terhadap kinerja pegawai di Dinas Pemberdayaan Masyarakat Dan Desa Kabupaten Labuhanbatu Selatan. Besarnya pengaruh variabel sikap kerja terhadap kinerja pegawai di Dinas Pemberdayaan Masyarakat Dan Desa Kabupaten Labuhanbatu Selatan sebesar 0.285 atau $28.50 \%$. Hasil penelitian ini sejalan dengan hasil penelitian terdahulu dari Chres F.P Laoh et.al (2016), Famella et.al
(2015), Fonny Corryda Rahayu (2013), dan Alias et.al (2018), kesemuanya menarik kesimpulan sikap kerja berpengaruh positif dan signifikan terhadap kinerja. Artinya semakin baik sikap kerja pegawai maka akan memberikan kontribusi positif terhadap pekerjaan yang menjadi tanggungjawabnya, karena sikap kerja merupakan salah satu faktor pendorong perilaku seseorang dalam aktivitas organisasi yang bertujuan untuk kemajuan organisasi itu sendiri. Sikap kerja merupakan keyakinan yang mengandung aspek kognitif, konatif, dan afektif yang merupakan kesiapan mental psikologis untuk bereaksi dan bertindak secara positif atau negatif terhadap objek tertentu. Pegawai yang lebih terlibat dalam pekerjaannya adalah pegawai yang memiliki kinerja yang baik dibandingkan dengan pegawai yang memiliki sikap tidak baik terhadap pekerjaannya, dengan kata lain sikap yang lebih baik terhadap pekerjaan menghasilkan peningkatan kinerja pegawai. 
3.5. Pengaruh Kepemimpinan, Pengawasan dan Sikap Kerja Terhadap Kinerja Pegawai Dinas Pemberdayaan Masyarakat Dan Desa Kabupaten Labuhanbatu Selatan

Untuk mengetahui pengaruh kepemimpinan, pengawasan dan sikap kerja terhadap kinerja pegawai di Dinas Pemberdayaan Masyarakat dan Desa Kabupaten Labuhanbatu Selatan digunakan uji-F, dengan ketentuan sebagai berkut :

a. Jika nilai $\mathrm{F}_{\text {hitung }}>\mathrm{F}_{\text {tabel }}$ dan nilai probabilitas $(\mathrm{p})<$ tingkat signifikansi

Tabel 9. Anova ${ }^{\mathrm{b}}$ pengaruh kepemimpinan, pengawasan dan sikap kerja terhadap kinerja

\begin{tabular}{|l|l|r|r|r|r|c|}
\hline \multirow{3}{*}{ Model } & & $\begin{array}{c}\text { Sum of } \\
\text { Squares }\end{array}$ & \multicolumn{1}{c|}{ df } & $\begin{array}{c}\text { Mean } \\
\text { Square }\end{array}$ & \multicolumn{1}{c|}{ F } & \multicolumn{1}{c|}{ Sig. } \\
\hline 1 & Regression & 194.196 & 3 & 64.732 & 12.289 & $.000^{\mathrm{a}}$ \\
\cline { 2 - 8 } & Residual & 168.554 & 32 & 5.267 & & \\
\cline { 2 - 8 } & Total & 362.750 & 35 & & & \\
\hline
\end{tabular}

Hasil pengolahan data, 2021

Berdasarkan Tabel 9. out put SPSS "Anova" diatas diketahui nilai $\mathrm{F}_{\text {hitung }}>\mathrm{F}_{\text {tabel }}$ $(12.289>2,66)$ dan nilai signifikasi $0,000<$ 0,05 , sehingga $\mathrm{H}_{0}$ ditolak dan $\mathrm{H}_{1}$ diterima. Artinya variabel kepemimpinan, pengawasan dan sikap kerja secara simultan atau bersamasama berpengaruh positif dan signifikan terhadap kinerja pegawai di Dinas Pemberdayaan Masyarakat Dan Desa Kabupaten Labuhanbatu Selatan. Oleh karena itu, maka sangat penting untuk memperhatikan faktor-faktor yang mendukung terbentuknya kepemimpinan, pengawasan dan sikap kerja. Artinya, pimpinan harus tetap berusaha konsisten dalam hal mempengaruhi para bawahan sehingga mereka bisa mengikuti karakter dari seorang pemimpin tersebut yang dapat menjadi teladan. Pemimpin juga harus
$5 \%(\alpha=0,05)$ maka hipotesis penelitian $\left(\mathrm{H}_{1}\right)$ diterima dan $\mathrm{H}_{0}$ ditolak.

b. Jika nilai $F_{\text {hitung }}<\mathrm{F}_{\text {tabel }}$ dan nilai probabilitas $(\mathrm{p})>$ tingkat signifikansi $5 \%(\alpha=0,05)$ maka hipotesis penelitian $\left(\mathrm{H}_{1}\right)$ ditolak dan $\mathrm{H}_{0}$ diterima.

Penelitian ini menggunakan taraf signifikansi $(\alpha \quad 0,05)$ dan Derajat Kebebasan (DK) dengan ketentuan numerator : jumlah variabel -1 atau $4-1=3$, dan jumlah sampel dikurang 4 atau $36-4=32$. Dengan ketentuan tersebut, diperoleh nilai $\mathrm{F}_{\text {tabel }}$ sebesar 2,66. terus mengawasi para bawahan sehingga mereka dapat diperhatikan apabila melakukan kesalahan dapat langsung diperbaiki ataupun berhasil dalam pekerjaan mereka dapat diberikan penghargaan.

\subsection{Uji Determinan}

Uji determinan adalah untuk melihat seberapa besar pengaruh variabel kepemimpinan, pengawasan dan sikap kerja terhadap kinerja pegawai di Dinas Pemberdayaan Masyarakat dan Desa Kabupaten Labuhanbatu Selatan secara simultan, maka dapat dilihat dari hasil perhitungan dalam model summary, khususnya angka $\mathrm{R}_{\text {Square }}$ dibawah ini :

\section{Tabel 10. Uji Determinasi}

\begin{tabular}{|l|r|r|r|r|}
\hline Model & $\mathrm{R}$ & R Square & $\begin{array}{c}\text { Adjusted R } \\
\text { Square }\end{array}$ & Std. Error of the Estimate \\
\hline 1 & $.732^{\mathrm{a}}$ & .535 & .492 & 2.29506 \\
\hline
\end{tabular}

Hasil pengolahan data, 2021

Berdasarkan Tabel 10 . out put SPSS "Model summary" diatas, diperoleh nilai $\mathrm{R}_{\text {Square }}$ $\left(r^{2}\right)$ adalah 0,535. Nilai tersebut mempunyai maksud bahwa pengaruh variabel kepemimpinan, pengawasan dan sikap kerja terhadap kinerja pegawai di Dinas Pemberdayaan Masyarakat Dan Desa Kabupaten Labuhanbatu Selatan sebesar
$53.50 \%$, sedangkan sisanya sebesar $46.50 \%$ $(100 \%-53.50 \%)$ dipengaruhi oleh faktor-faktor lain yang tidak diteliti. Dengan kata lain variabilitas kinerja pegawai di Dinas Pemberdayaan Masyarakat Dan Desa Kabupaten Labuhanbatu Selatan dapat diterangkan oleh variabel kepemimpinan, pengawasan dan sikap kerja sebesar $53.50 \%$, 
sedangkan sisanya sebesar $46.50 \%$ disebabkan oleh variabel-variabel lain diluar model penelitian ini.

\section{Kesimpulan}

Berdasarkan pada analisis dan evaluasi data pada bab sebelumnya, maka dapat ditarik kesimpulan sebagai berikut :

1) Variabel kepemimpinan berpengaruh positif dan signifikan terhadap kinerja pegawai di Dinas Pemberdayaan Masyarakat dan Desa Kabupaten Labuhanbatu Selatan.

2) Variabel pengawasan berpengaruh positif dan signifikan terhadap kinerja pegawai Dinas Pemberdayaan Masyarakat dan Desa Kabupaten Labuhanbatu Selatan.

3) Variabel sikap kerja berpengaruh positif dan signifikan terhadap kinerja pegawai di Dinas Pemberdayaan Masyarakat Dan Desa Kabupaten Labuhanbatu Selatan.

4) Variabel kepemimpinan, pengawasan dan sikap kerja berpengaruh positif dan signifikan terhadap kinerja pegawai di Dinas Pemberdayaan Masyarakat dan Desa Kabupaten Labuhanbatu Selatan.

\section{DAFTAR PUSTAKA}

Buku :

Colquitt, J. A., LePine, J. A., and Wesson., (2009) Organizational Behavior: Improving Performance and Commitment in the Workplace, New York, McGraw Hill, pp. 37

Dessler, Gary. (2012), Manajemen Sumber Daya Manusia (Jilid 2), Jakarta : Indeks.

Hasibuan, Malayu S. P. (2012), Manajemen Sumber Daya Manusia, Edisi Revisi Jakarta : PT. Bumi Aksara.

Irham Fahmi (2014), Manajemen Kinerja Teori dan Aplikasi, Cetakan kedua. Bandung: Alfabeta

Mangkunegara Anwar Prabu, (2013), Evaluasi Kinerja Sumber Daya Manusia, Cetakan 5, Bandung : Refika Aditama

Mangkuprawira, Sjafri. (2014). Manajemen Sumber Daya Manusia Strategik. Cetakan keempat, Jakarta, Penerbit Ghalia Indonesia

Marwansyah (2015), Manajemen Sumber Daya Manusia. Edisi Kedua, Bandung: Alfabeta

Peraturan Pemerintah (PP) Nomor 30 Tahun 2019 tentang Penilaian Kinerja Pegawai Negeri Sipil (PNS)

Rivai, Veithzal dan Sagala, Ella Jauvani, (2014), Manajemen Sumber Daya Manusia Untuk Perusahaan : Dari Teori ke Praktek. Jakarta : PT. Rajagrafindo Persada
Robbins S.P dan Judge, (2014), Perilaku Organisasi, Buku 1 Edisi 14. Terjemahan Diana Angelica, Jakarta, Salemba Empat

Samsudin, Sadili (2013), Manajemen Sumber Daya Manusia, Bandung: CV. Pustaka Setia.

Sedarmayanti. (2014). Good Governance (Kepemerintahan Yang Baik), Bandung : Mandar Maju

Siagian, Sondang. (2014), Manajemen Sumber Daya Manusia, Cetakan 15, Jakarta: Bumi Aksara

Sugiyono. (2017), Metode Penelitian Kuantitatif, Kualitatif, dan R\&D, Bandung : CV. Alfabeta

Sutrisno, Edy (2014). Manajemen Sumber Daya Manusia, Kencana Prenada Media Group Jakarta

Terry George dan Rue, Leslie W (2011), DasarDasar Manajemen, Cetakan Ketujuh Bumi Aksara Jakarta

Winardi (2016), Kepemimpinan Dalam Manajemen, Jakarta: PT. Rineka Cipta

Yukl, G. (2013), Kepemimpinan Dalam Organisasi, Edisi Indonesia (kelima), Cetakan kedua, Jakarat Penerbit PT Indeks.

\section{Jurnal :}

Agus Marimin (2011), Pengaruh gaya kepemimpinan, motivasi kerja, dan budaya organisasi terhadap kinerja karyawan pada Bank Muamalat Indonesia Cabang Surakarta, Jurnal Manajemen dan Bisnis Sriwijaya Vol.3 No.16

Ali, A.Y.S., Dahie, A.M., dan Ali, A.A. (2016). Teacher Motivation and Leadership, the Mediating Effect of Job Performance: Survey from Secondary Schools in Mogadishu. International Journal of Education and Social Science Vol. 3 No. 1. January 2016

Chres F.P Laoh, Bernhard Tewal, dan Sem G Oroh (2016), Pengaruh Pengetahuan, Keterampilan dan Sikap Kerja Terhadap Kinerja Pegawai (Studi Kasus Pada PT. National Nobu Bank Area Manado). Jurnal Berkala Ilmiah, Vol 16 No. 04

Elvandari, Erlina Oktafia (2015), Pengaruh Lingkungan Kerja Dan Pengawasan Terhadap Kinerja Karyawan PT. Tripilar Betonmas Salatiga Tahun 2014/2015, thesis, Universitas Muhammadiyah Surakarta, http://eprints.ums.ac.id/32830/

Fauzi, A. (2013). Pengaruh Kepemimpinan, Kecerdasan Individuonal dan Motivasi 
terhadap Kinerja Pegawai di SMA, Jurnal Manajemen Pendidikan Vol 1, No 1

Firda Nova Manullang (2011), Pengaruh Pengawasan Dan Disiplin Terhadap Tingkat Kinerja Karyawan (Study Kasus Pada PT. Putra Jaya Sentosa Pekanbaru), https://media.neliti.com/media/publications/ 31181-ID

Famella, Sri Wahyu Lelly Hana Setyanti, Ana Mufidah (2015), Pengaruh Keterampilan Kerja, Pengalaman Kerja, dan Sikap Kerja Terjadap Kinerja Karyawan Pada Perusahaan Rokok Gagak Hitam Kabupaten Bondowoso. Jurnal Universitas Jember.

Fonny Corryda Rahayu (2013), Pengaruh Sikap Kerja dan Komitmen Organisasi Terhadap Kinerja Karyawan Pada PT. Graha Agung Kencana Group Surabaya. Jurnal Universitas Pembangunan Nasional "Veteran" Jawa Timur

Osabiya Babatunde, Ikenga Emem (2015), The Impact of Leadership Style on Employee's Performance in an Organization, Public Policy and Administration Research, Vol.5, No.1, ISSN 2224-5731(Paper) ISSN 22250972

Rahayu Saputri, Nur Rahmah Andayani, (2018), Pengaruh Kepemimpinan Dan Motivasi Kerja Terhadap Kinerja Pegawai Pada Departemen Production Di PT Cladtek Bi-Metal Manufacturing Batam, Journal of Applied Business Administration Vol2, No 2,September 2018, hlm. 141-151.eISSN:2548-9909

Rara Saraswati (2015), Pengaruh Pengawasan Dan Lingkungan Kerja Terhadap Kinerja Karyawan Bagian Pemasaran PT. Indofood Sukses Makmur. Tbk di Pekanbaru, JOM FEKON Vol. 2 No. 1

Rd. Kresna Yudi Kusumah, Sri Suwarsi, Dudung Abdurrahman (2017), Pengaruh Kompetensi Dan Sikap Kerja Terhadap Kinerja Karyawan Di Hashi Ramen Bar Dan Resto Cimahi, SPeSIA, Prosiding Manajemen, Vol. 3, No.2

Sami'an dan Estu Aprilian N.W, (2013), Pengaruh Kepemimpinan Dan Pengawasan Terhadap Kinerja Karyawan PT. Kereta Api Indonesia (Persero) Di Kantor DAOP IV Semarang, Jurnal Pendidikan Ilmu Sosial, Vol. 23, No. 1. 